\title{
Provenance of Eocene river sediments from the central northern Sierra Nevada and implications for paleotopography
}

\author{
M. Robinson Cecil, ${ }^{1}$ Mihai N. Ducea, ${ }^{2}$ Peter Reiners, ${ }^{2}$ George Gehrels, ${ }^{2}$ \\ Andreas Mulch, ${ }^{3,4}$ Charlotte Allen, ${ }^{5}$ and Ian Campbell ${ }^{5}$ \\ Received 2 April 2010; revised 18 August 2010; accepted 31 August 2010; published 14 December 2010.
}

[1] Geochronology of fluvial deposits can be used to characterize provenance, the paleotopography of sediment source regions, and the development of regional drainage systems. We present $\mathrm{U}-\mathrm{Pb}$ and $(\mathrm{U}-\mathrm{Th}) / \mathrm{He}$ ages of detrital zircon grains from Eocene gravels preserved in several paleoriver systems along the western flank of the central and northern Sierra Nevada. These ages allow us to trace the sourcing of detritus in paleorivers and to constrain the evolution of the Sierra Nevada range front. $\mathrm{U}-\mathrm{Pb}$ zircon age distributions are bimodal, with a dominant peak between 110 and $95 \mathrm{Ma}$ and smaller but significant peaks in the Middle to Late Jurassic, matching the predominant ages of the Sierra Nevada batholith. A small fraction $(<6 \%)$ of grains has pre-Mesozoic ages, which consistently match ages from prebatholithic assemblages within the northern part of the range. (U-Th)/He ages of a subset of doubledated zircons cluster between 114 and $74 \mathrm{Ma}$ and are consistent with batholithic (U-Th)/He cooling ages in the northern Sierra. Our results indicate that the Eocene river systems in the central northern Sierra Nevada likely had proximal headwaters and had relatively steep axial gradients, draining smaller areas than was commonly thought. This also suggests that the northern Sierra Nevada would have had an established drainage divide and would have acted as a major topographic barrier during the early to mid-Cenozoic. The data presented here support a model of the Eocene northern Sierra Nevada characterized by a western slope with a gradient broadly similar to that of today. Citation: Cecil, M. R., M. N. Ducea, P. Reiners, G. Gehrels, A. Mulch, C. Allen, and I. Campbell (2010), Provenance of Eocene river sediments from the central northern Sierra Nevada and implications for paleotopography, Tectonics, 29, TC6010, doi:10.1029/2010TC002717.

\footnotetext{
${ }^{1}$ Division of Geological and Planetary Sciences, California Institute of Technology, Pasadena, California, USA. USA.

${ }^{2}$ Department of Geosciences, University of Arizona, Tucson, Arizona,

${ }^{3}$ Biodiversity and Climate Research Centre, Frankfurt, Germany.

${ }^{4}$ Institut für Geowissenschaften, Goethe Universität Frankfurt, Frankfurt, Germany.

${ }^{5}$ Research School of Earth Sciences, Australian National University, Canberra, ACT, Australia.

Copyright 2010 by the American Geophysical Union. 0278-7407/10/2010TC002717
}

\section{Introduction}

[2] The northern Sierra Nevada is characterized by substantial relief (2-2.5 km vertical elevation over $100 \mathrm{~km}$ in the central and northern parts of the range) and average crestal elevations of $>2200 \mathrm{~m}$ above sea level (masl). Geodynamically, the northern part of the range behaves as a semirigid microplate, which is coupled to the Great Valley [Argus and Gordon, 1991; Dixon et al., 2000] and bounded to the east by the Sierran frontal fault system and to the west by the San Andreas plate boundary. Physiographically, the Sierra Nevada is a northwest-southeast trending mountain range approximately $600 \mathrm{~km}$ in length and $100 \mathrm{~km}$ in width and is bounded to the east by the Basin and Range province and to the west by the Great Valley (Figure 1). With the exception of the southernmost Sierra, which is broken by a system of late Cenozoic faults [Mahéo et al., 2009], the Sierran block as a whole apparently exhibits little internal deformation. The range bears an asymmetrical profile with a steeply sloping eastern margin and a more gently dipping western margin, which has long been interpreted to be the result of westward block tilting [e.g., Lindgren, 1911; Christensen, 1966; Huber, 1981; Unruh, 1991]. Westward tilting, initiated by the development of the east side-down normal faults along the Sierran front, is thought to have generated uplift at the range crest since the time of faulting (circa 5 Ma [Wakabayashi and Sawyer, 2001]). The degree to which the Sierra has been tilted and the amount of surface uplift interpreted to have occurred in the late Cenozoic, however, remains controversial.

[3] Many data sets have been brought to bear on this issue of recent range-wide uplift. Geomorphic reconstructions of paleochannels preserved in the western Sierra have been used to argue for an increase in slope following Eocene through Miocene deposition of sediments in the channels [Lindgren, 1911; Hudson, 1955, 1960; Huber, 1981, 1990; Jones et al., 2004]. A marked increase in downcutting rates of southern Sierra rivers from $\sim 1.3$ to $2.7 \mathrm{~mm} / \mathrm{yr}$ at circa $3 \mathrm{Ma}$ has also been suggested as evidence of an additional phase of Late Cenozoic surface uplift and incision [Wakabayashi and Sawyer, 2001] into significant preexisting topography [Stock et al., 2005, 2004]. Late Cenozoic surface and/or rock uplift is not reflected in low-temperature thermochronometric data, however, which indicate protracted range-wide long-term exhumation rates in the mid-Cenozoic [House et al., 2001; Clark et al., 2005; Cecil et al., 2006]. In fact, the distribution of variable (U-Th)/He ages across modern canyons in the south central Sierra has been used to argue for the presence of high-relief paleocanyons in the Paleogene, 


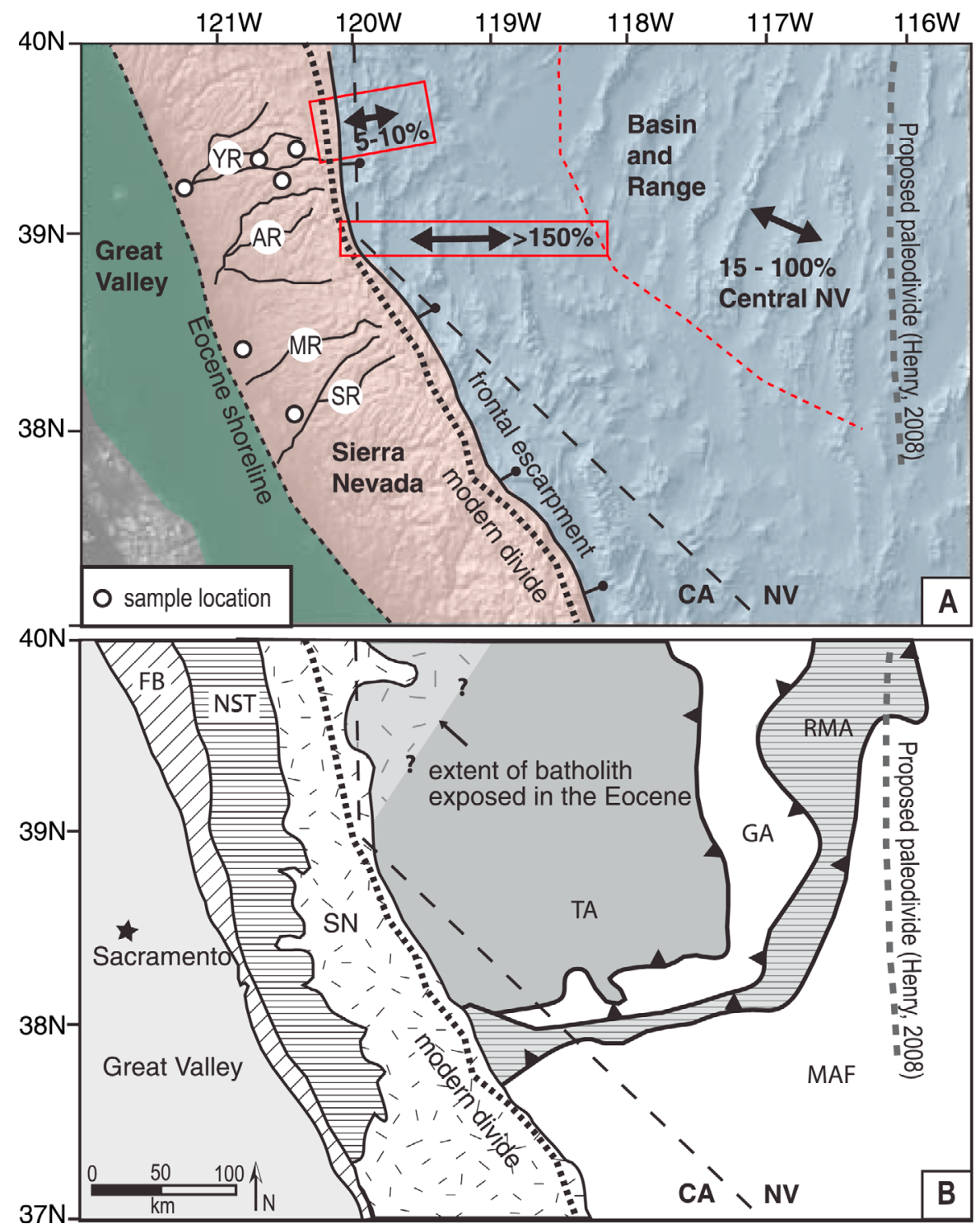

Figure 1. (a) Digital elevation model of the Sierra Nevada and west central Nevada showing presentday topography and location of the modern drainage divide. Sample locations are shown, and major modern rivers discussed in text are outlined. AM, American River; MR, Mokelumne River; SR, Stanislaus River; YR, Yuba River. Mapped Tertiary extension in Nevada is modified after Van Buer et al. [2009] and Cassel et al. [2009b], and extension estimates are from Smith et al. [1991], Surpless et al. [2002], and Faulds et al. [2005]. (b) Generalized geologic basement map of the same area, showing source terranes and assemblages and their associated boundaries. Map modified after Gehrels and Miller [2000]. Location of proposed paleodivide is from Henry [2008]. FB, Foothills belt; GA, Golconda allochthon; MAF, Miogeocline and Antler foreland basin strata; NST, northern Sierra terrane; RMA, Roberts Mountain allochthon; SN, Sierra Nevada batholith; TA, Triassic assemblages.

implying a decrease in relief and crestal elevations since $\sim 60$ Ma [House et al., 1998; Braun, 2002].

[4] Stable isotope geochemistry has been used to both constrain the timing of a rain shadow effect in the Great Basin east of the Sierra Nevada [Poage and Chamberlain, 2002], and to estimate paleoaltitudes of the Sierra Nevada-Great Basin region [Horton et al., 2004; Mulch et al., 2006, 2008; Crowley et al., 2008; Cassel et al., 2009a; Hren et al., 2010]. Those data indicate the presence of a Miocene rain shadow and Eocene through Pleistocene western gradients similar to present day, which is difficult to reconcile with earlier geomorphic studies. Paleoaltimetric studies strengthen the case for a high interior upland (termed the Nevadaplano [DeCelles, 2004]) existing to the east of the Sierra Nevada [Horton et al., 2004; Cassel et al., 2009a]. It should be emphasized, however, that these seemingly contradictory data sets are complicated by the fact that the northern (north of $37.5^{\circ} \mathrm{N}$ ) and southern parts of the Sierra Nevada are 
markedly different in many respects and may not share a common topographic evolution.

[5] The paleotopography of the northern Sierra Nevada and the paleotopographic and geodynamic relationship between the ancestral Sierra and the Nevadaplano to the east remain unclear, partly due to deformation east of the Sierra Nevada associated with the westward encroachment of Basin and Range faulting, and the relative paucity of Cenozoic geology preserved within the Sierra. We present new detrital zircon $\mathrm{U}-\mathrm{Pb}$ and $(\mathrm{U}-\mathrm{Th}) / \mathrm{He}$ ages from Eocene river sediments, which we use to assess the relative contributions of sediment sources from within the Sierra Nevada and basement terranes to the east. Our aims are twofold: (1) to constrain the upstream drainage areas of paleorivers and (2) to estimate the position of the Eocene drainage divide. Such analyses allow us to estimate depositional gradients and to create a model of large-scale range paleotopography. These issues have implications for the rock and surface uplift history of the Sierra Nevada, which is key to determining the geodynamic processes responsible for the creation and/or maintenance of high topography over geologic timescales.

\section{Geologic Framework and Characterization of Fluvial Deposits}

[6] The modern Sierra Nevada is the exposed root of a Mesozoic magmatic arc comprising primarily midcrustal intrusive rocks, as well as older plutonic bodies (i.e., Devonian Bowman Lake batholith), and framework metasedimentary and metavolcanic belts [Bateman and Wahrhaftig, 1966]. Batholithic ages in the Sierra range from 248 to 80 $\mathrm{Ma}$, with major pulses of magmatism occurring between 160-150 Ma and 110-85 Ma [Coleman and Glazner, 1998; Ducea, 2001]. Unlike the southern Sierra Nevada, the exposed portions of which are almost entirely granitoids, the central and northern parts of the range preserve a sequence of Cenozoic clastic and volcaniclastic units. The base of the Cenozoic section comprises coarse gold-bearing gravels of variable thickness, which are found in west dipping bedrock paleochannels and are capped by Neogene volcaniclastics (Figure 2). These paleochannel systems can be traced from the Paleogene shoreline upslope to below the range crest ( $2000 \mathrm{~m})$, and have been inferred by some authors to extend east into central Nevada [Huber, 1990; Wakabayashi and Sawyer, 2001; Garside et al., 2005].

[7] East of the Sierra Nevada, the basement geology is characterized by a series of Neoproterozoic through Jurassic basement terranes comprising mainly continental margin strata and ocean floor assemblages. Central eastern Nevada is underlain by Neoproterozoic through early Mesozoic Cordilleran miogeoclinal rocks, although only upper Paleozoic and younger miogeoclinal strata would have been exposed in the Eocene [Van Buer et al., 2009]. To the northwest, sandstones, shales, and cherts of the Roberts Mountain and Golconda allochthons were thrust over miogeoclinal strata during the Paleozoic Antler and Sonoma orogenies, respectively [Schweickert and Snyder, 1981; Gehrels et al., 2000; Riley et al., 2000]. During the Triassic, clastic shallow marine sequences accumulated on Golconda rocks (Figure 1). Zircon age signatures from these terranes are dominated by recycled Precambrian grains, which have distinct population clusters, and are unlike zircon spectra expected for Sierran sources, which should reflect primarily Mesozoic batholithic ages.

[8] The gold-bearing fluvial gravels in the northern Sierra are thought to have been deposited in the middle Eocene, based upon molluscan faunal constraints from the correlative Ione Formation (lower Sierran foothills) [Creely and Force, 2007] and radiometric ages of overlying Oligocene volcanics [Cassel et al., 2009b; Henry, 2008]. They can be divided into two groups: a coarse lower unit, dominated by pebble to boulder-sized clasts, which typically occupies narrow channel thalwegs, and an upper unit, which is thicker, finer grained, and characterized by trough cross stratification, lenticular bedding, and discontinuous bands of imbricated pebbles and cobbles [Yeend, 1974; Clark, 1979]. Commonly, the lower gravels are not found stratigraphically in place, but rather as man-made, voluminous lag deposits on the basement floors of abandoned hydraulic mines. Where exposed in place, they lie unconformably atop steeply dipping metasediments of the Calaveras and Shoo Fly complexes, and can be up to $\sim 35 \mathrm{~m}$ thick. Lower gravel conglomerates are clast supported and uniformly coarse, with clasts having average $b$ axis diameters of $>64 \mathrm{~mm}$. Clasts are typically subrounded and appear to be of local lithologic affinity [Yeend, 1974].

[9] The upper gravels, from which our samples were collected, are medium to coarse-grained sands, interbedded with discontinuous lenses of both imbricated pebbles and fine-grained sands and silts (total thickness locally of over $100 \mathrm{~m}$ ). Continuous, but thinner, silt and clay horizons are also present. This paper uses the provenance of the Eocene upper gravels to constrain the catchments being drained by Sierran paleoriver systems and to estimate the slope of the western Sierra Nevada and the position of the Eocene drainage divide.

\section{Analytical Methods}

[10] Sand, pebbles, and cobbles from the Eocene upper gravel unit were sampled from six different localities along the ancestral Yuba, American, Mokelumne, and Stanislaus Rivers, located on the western flank of the central northern Sierra Nevada (Figure 3). This allowed us to analyze the provenance of zircon grains from multiple Paleogene river systems, thereby placing the topographic structure of the Sierra Nevada into a regional context. Zircons were separated by standard rock crushing and magnetic/density procedures. Detrital zircon U-Pb geochronologic analysis for samples 1, 2, 4 and 5 was conducted at the University of Arizona LaserChron center using LA-MC-ICP-MS (laser ablation multicollector inductively coupled plasma mass spectrometry) (details of analytical method are explained by Gehrels et al. [2008]). Samples 3a-3d and 6 were analyzed at the Australian National University using Q-ICP-MS (quadrupole-ICP-MS). Details of this analytical method are outlined by Reiners et al. [2005].

[11] For each sample, a random population of up to $\sim 100$ grains was individually analyzed. With the exception of dark pinkish crystals, which often had pre-Mesozoic 
ages, there was little correlation between the calculated $\mathrm{U}-\mathrm{Pb}$ age and zircon appearance. To maximize precision, for zircon grains younger than $1.0 \mathrm{Ga}$, the ${ }^{206} \mathrm{~Pb} /{ }^{238} \mathrm{U}$ age is reported, whereas for grains older than this, the ${ }^{206} \mathrm{~Pb} /{ }^{207} \mathrm{~Pb}$ is used. In the case of the North Columbia sample, all zircon grains with a discernable color $(\mathrm{n}=35)$ were handpicked, mounted separately, and analyzed. Those measurements were then added to the Precambrian ages calculated from the original North Columbia sample (with grains selected randomly) and plotted as North Columbia Precambrian. All detrital zircon data (727 total zircon ages) are plotted as relative probability curves.

[12] In addition to $\mathrm{U}-\mathrm{Pb}$ ages, eleven zircon grains from the Blue Lead sand sample were analyzed for (U-Th)/He ages (see Reiners et al. [2005] for zircon double-dating methods) (all $\mathrm{U}-\mathrm{Pb}$ and $(\mathrm{U}-\mathrm{Th}) / \mathrm{He}$ zircon data with appropriate concordance and precision are included in Data Sets S1 and S2). ${ }^{1}$

\section{Results}

[13] The samples reported here generally have similar age distributions, with most zircon grains yielding ages between 175 and 85 Ma. Samples have two distinct peaks: a larger one at 110-95 Ma and smaller, but significant, peaks in the Middle to Late Jurassic. In contrast to the other samples, where the large age peak defines a narrow age range, the Wallens sample has a broad, flat peak, spanning an age range of $30 \mathrm{Myr}$. (124-91 Ma), which composes $78 \%$ of the total zircon population. The fraction of Jurassic-age grains is higher in samples collected farther west and also increases with increasing grain size, such that at a single collection site, pebble samples have more Jurassic grains than the sand fraction, but many fewer Jurassic grains than the cobble fraction (Figure 4a). Zircon grains from Orleans Flat were separated from 6 cobbles and have ages between 399 and $325 \mathrm{Ma}$. Random analysis of zircon grains shows that $<6 \%$ of any sample population has grains of Precambrian age. The Precambrian zircon subset $(n=42 ; 35$ of which were not randomly selected) from the North Columbia sample site has a number of significant grain populations, and is characterized by age probability peaks at circa $1023 \mathrm{Ma}, 1830 \mathrm{Ma}$, $2480 \mathrm{Ma}$, and $2660 \mathrm{Ma}$.

[14] Eleven zircon grains from the Blue Lead sand sample have $\mathrm{U} / \mathrm{Pb}$ ages ranging from $87 \mathrm{Ma}$ to $2.5 \mathrm{Ga}$, and corresponding (U-Th)/He ages ranging from 74 to $114 \mathrm{Ma}$ (see Data Set S2). There is no significant correlation between $\mathrm{U} / \mathrm{Pb}$ and $(\mathrm{U}-\mathrm{Th}) / \mathrm{He}$ age. The distribution of reported $(\mathrm{U}-\mathrm{Th}) / \mathrm{He}$ ages overlaps with, but is slightly offset from the range of (U-Th)/He zircon bedrock ages reported by Cecil et al. [2006].

\section{Discussion}

\subsection{Provenance of Eocene Fluvial Deposits}

[15] The detrital zircon data presented here provide new information about the provenance of Eocene river gravels and, thereby, the bedrock sediment sources of Eocene river

\footnotetext{
${ }^{1}$ Auxiliary materials are available at ftp://ftp.agu.org/apend/tc/ 2010 tc002717.
}

systems in the central and northern Sierra Nevada. The age distribution patterns in our analyses are a close match to both apparent intrusive flux data for the southern Sierra Nevada [Ducea, 2001] and the age-area distribution of preEocene plutonic rocks in the northern Sierra Nevada (this study; Figure 4b). Both data sets reveal two magmatic events in the Sierra Nevada: one in the Jurassic (160-150 Ma) and another, much larger event in the Late Cretaceous (110-95 Ma), a pattern reflected in our detrital zircon probability density plots. To first order, this is consistent with derivation of zircon grains in the Eocene fluvial samples overwhelmingly from local Sierra Nevada magmatic sources.

[16] In addition to the broad magmatic trend, there are a number of important patterns observed in the $\mathrm{U}-\mathrm{Pb}$ detrital zircon data consistent with local sourcing.

[17] 1. Samples collected from the westernmost Sierran foothills (Angel's Camp, Wallens, and Blue Lead) have a larger fraction of Jurassic aged zircons, whereas samples collected upslope to the east (Chalk Bluff and North Columbia) have age signatures dominated by Cretaceous grains. This is attributed to the pattern of pluton distribution in the central northern Sierra Nevada, where older plutons are emplaced into the western Foothills belt and younger Cretaceous plutons are found in the crestal areas (Figure 3).

[18] 2. The zircon age spectrum from the Angel's Camp sample reveals two small, but distinguishable age peaks at $167 \mathrm{Ma}$ and $148 \mathrm{Ma}$. The ages of these peaks match ages of smaller plutons (the Standard and Parrott's Ferry plutons from Sharp and Saleeby [1979]; the Woods Ridge granite and Granite Creek tonalite from Dodge and Calk [1987]) exposed to the southeast of the sample site.

[19] 3. The relative proportion of Jurassic grains in the samples from the Blue Lead hydraulic mine increases with grain size, owing to the fact that larger clasts (pebbles and cobbles) are more difficult to transport and are more likely derived from local Jurassic plutons.

[20] 4. In the case of the Orleans Flat sample, all of the cobbles sampled have zircon grains of a distinctive Devonian age and are likely shed from the Bowman Lake batholith located $<10 \mathrm{~km}$ upstream of the collection site. All of these patterns observed in the detrital zircon data indicate a local Sierra Nevada source for sediments deposited in all studied Paleogene channels.

[21] Because the North Columbia sample had the largest fraction of Precambrian grains (6\% of the larger randomly selected population), we chose to pick and analyze all recognizably old zircons from that sample in order to compare the age spectrum of these grains to those of nearby terranes in California and Nevada. A statistical comparison of the detrital Precambrian zircon spectra to those from California terranes indicates that the North Columbia Precambrian sample is similar to samples from the Shoo Fly Complex and the Shoo Fly overlap, assemblages in the northern Sierra terrane. However, these ages are also statistically similar to ages in the Golconda allochthon, the Roberts Mountain allochthon, and the Antler overlap assemblage (Figure 5). It is less similar, in terms of cumulative probability density, and proportion and overlap of peaks, to the miogeocline in Nevada. Given that the overwhelming abundance of Mesozoic zircon grains in Eocene river gravels is of local Sierran 


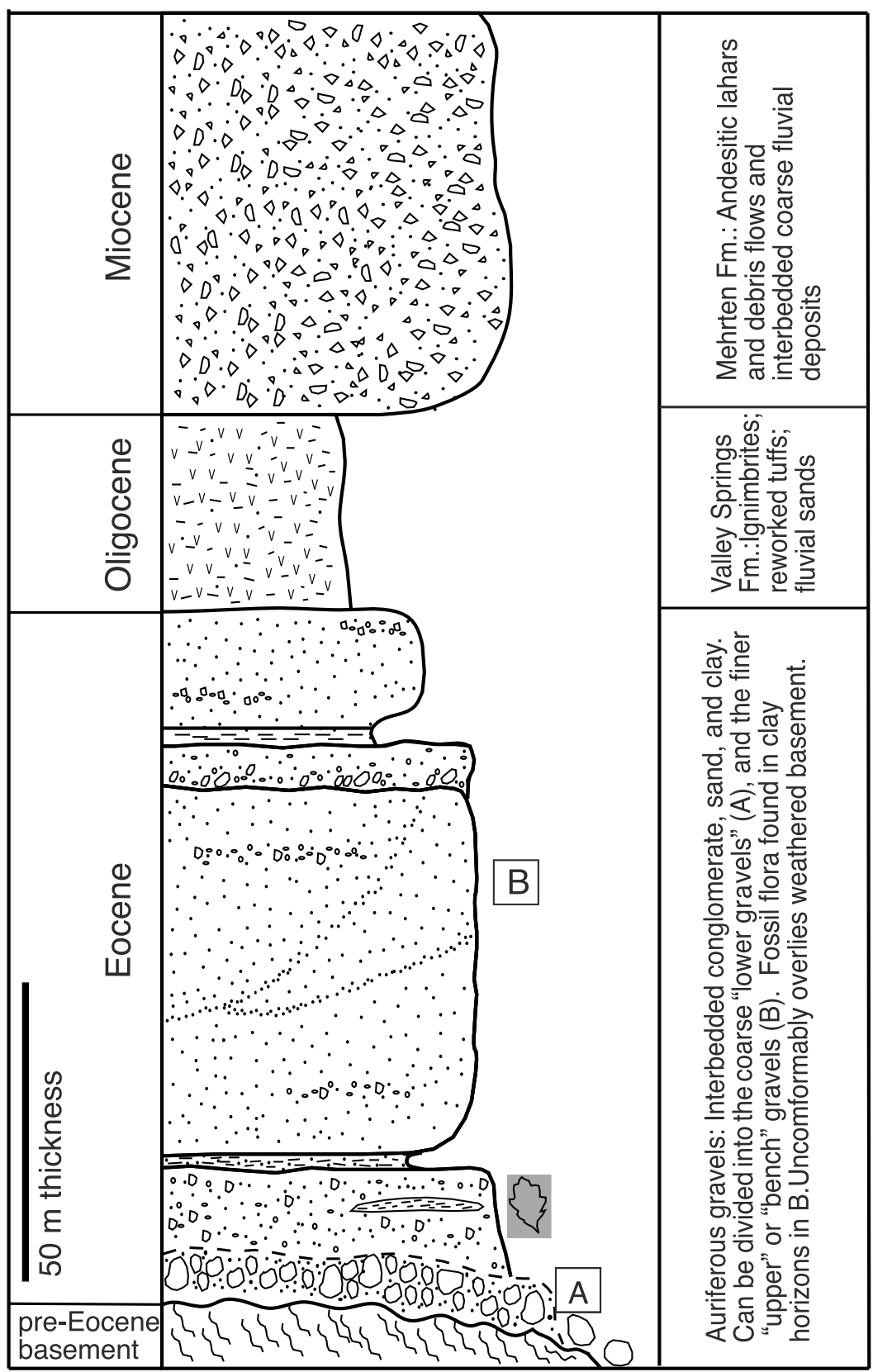

Figure 2. Generalized stratigraphic column for fluvial and volcanic deposits in the central northern Sierra Nevada. This is a composite drawn from measurements made at many different locations, as rarely are all units exposed at a single site. Unit thicknesses can vary between locations.

affinity, it is likely that Precambrian zircons were also derived from local Sierran Paleozoic metasedimentary rocks, although we cannot rule out derivation from source terranes to the east based only on detrital $\mathrm{U}-\mathrm{Pb}$ ages.

[22] U-Pb detrital zircon ages alone may not always uniquely constrain sediment provenance, especially when candidate source terranes contain zircons of similar crystallization age [Campbell et al., 2005; Reiners et al., 2005]. $(\mathrm{U}-\mathrm{Th}) / \mathrm{He}$ cooling ages on a subset of the same grains dated by $\mathrm{U} / \mathrm{Pb}$ also strengthen the case for local Sierra Nevada sources. Zircon He ages range from 74 to $113 \mathrm{Ma}$, similar to bedrock zircon He cooling ages of 65 to 91 Ma observed in northern Sierran granitoids [Cecil et al., 2006] (Figure 6 inset). The slightly younger range of cooling ages observed in the bedrock zircons is likely due to post-Eocene unroofing, and is consistent with slow exhumation rates $(\sim 0.03 \mathrm{~km} / \mathrm{Myr})$ estimated for the mid-Cenozoic [Clark et al., 2005; Cecil et al., 2006]. Importantly, the two Precambrian grains selected from the Eocene fluvial deposits for $\mathrm{He}-\mathrm{Pb}$ double dating also yield cooling ages similar to those of Sierran basement, suggesting that they share the same exhumation history as the range and are most likely derived from 


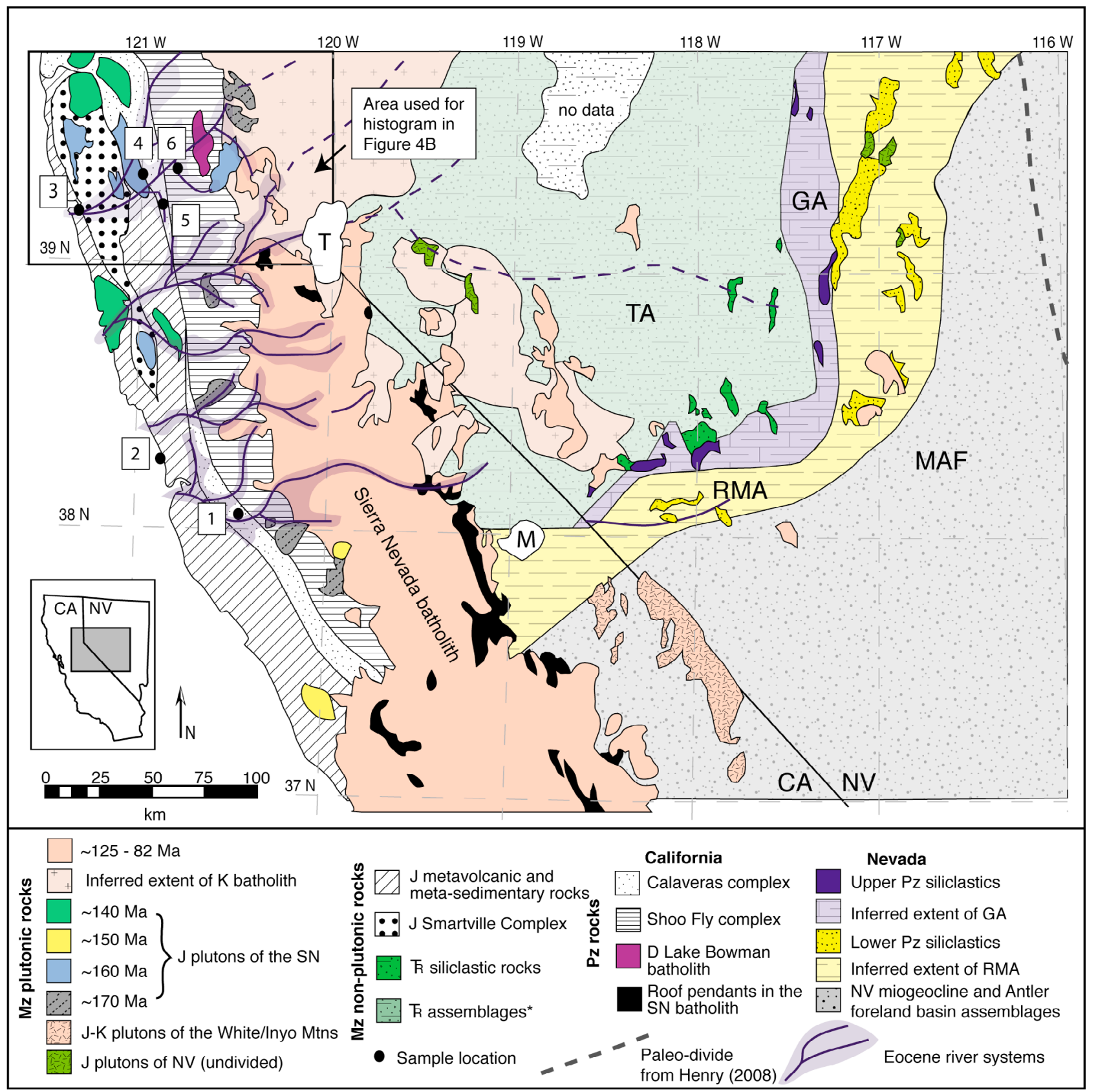

Figure 3. Generalized geologic map of the Sierra Nevada and central Nevada, modified after Irwin and Wooden [2001], Gehrels and Miller [2000], Crafford [2007], and Van Buer et al. [2009]. Pre-Eocene basement rocks in Nevada, where exposed, are shown in dark colors, and the inferred extent of basement terranes (compiled from Gehrels and Miller [2000], Crafford [2007], and Van Buer et al. [2009]) are shown in light colors. Sample locations are numbered and correspond to numbered age-probability plots in Figure 4a. Abbreviations are the same as for Figure 1b. Jurassic nonplutonic units make up the Foothills Belt (FB), and the Calaveras and Shoo Fly units make up the northern Sierra terrane (NST) shown in Figure 1b. T, Lake Tahoe; M, Mono Lake.

metamorphic belts within the Sierra Nevada. Pre-Mesozoic strata from Nevada basement terranes are not thought to have undergone significant burial or reheating, and have been shown to have much older zircon $\mathrm{He}$ cooling ages [Druschke et al., 2009] (Figure 6).

\subsection{Assumptions, Caveats, and Bias in the Detrital Zircon Record}

[23] Although both the $\mathrm{U} / \mathrm{Pb}$ and $(\mathrm{U}-\mathrm{Th}) / \mathrm{He}$ ages of zircons in our samples are consistent with local derivation 


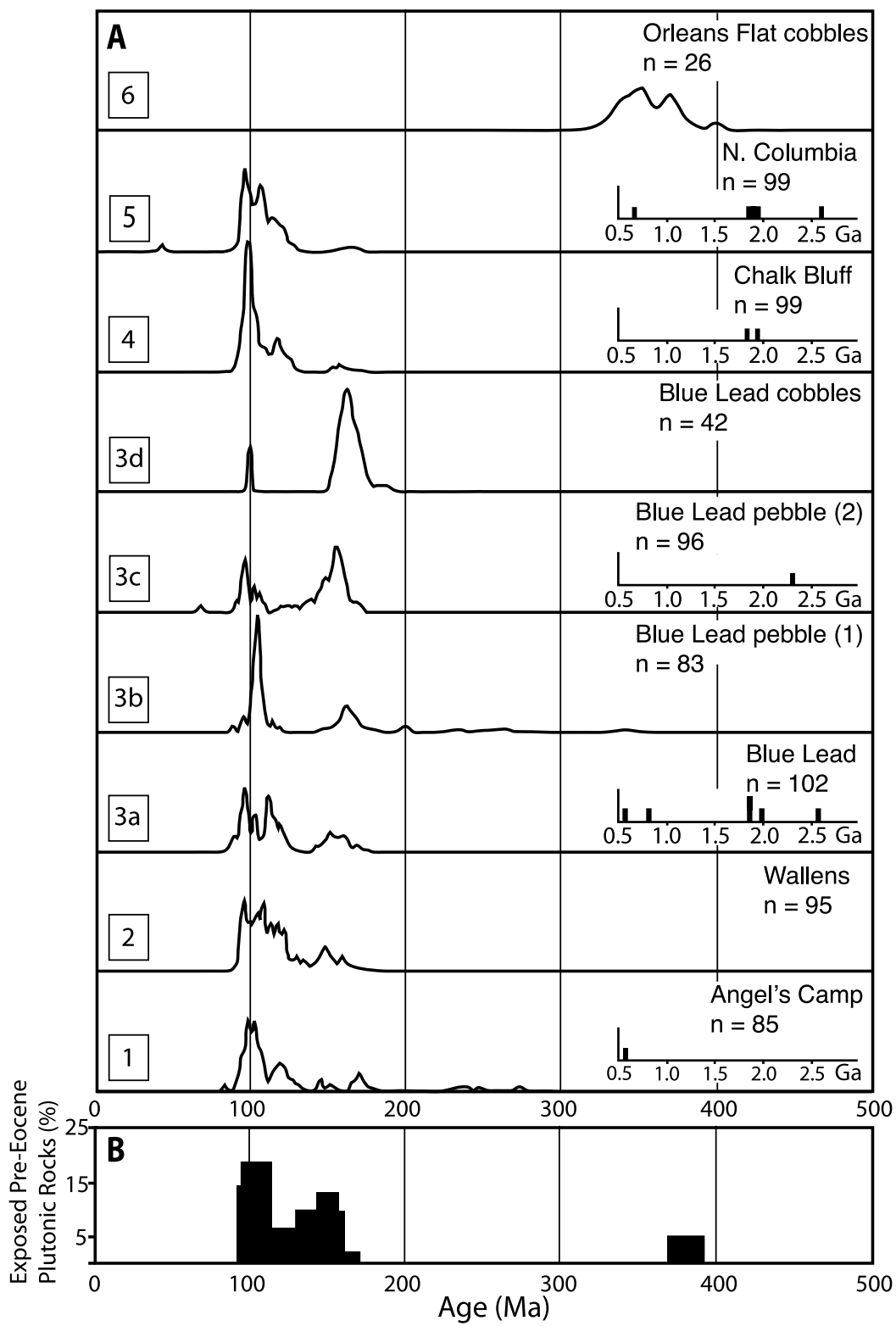

Figure 4. Detrital zircon age spectra for Eocene paleoriver deposits. (a) Data are plotted at two scales to emphasize the Mesozoic populations. Relative probability curves for Phanerozoic ages are plotted from 0 to 500 and inset are histograms of older grains plotted from 500 to $3000 \mathrm{Ma}$. (b) Relative age distribution of exposed pre-Eocene plutonic rocks in the northern Sierra Nevada (box in Figure 3).

from the Sierra Nevada, the question of whether those same signatures could be compatible with rivers draining a much greater area must be addressed. Fundamental to this type of provenance analysis is the assumption that detrital zircon populations from a given sample adequately represent the whole of the upstream paleodrainage area. In general, sample data may not be representative if (1) zircon grains were only transported limited distances or (2) granitoid terranes provide a greater, more concentrated source of zircon grains and their signals therefore artificially skew the zircon distributions. Specific to this study, detrital zircon age spectra may be misinterpreted if (1) Sierran-like zircon sources were present and exposed significantly farther east or (2) zircon-bearing rocks of Nevada basement terranes were not exposed in the Eocene. These general and casespecific complications regarding the interpretation of detrital zircon data are discussed below.

[24] It is possible that Eocene river systems were much longer and had headwaters in Nevada, but deposits collected in the Sierra Nevada are devoid of zircon populations with Nevada signatures due to limited transportability of zircon grains. If true, zircons collected at a given location would only ever reflect relatively local source terranes. This seems unlikely, however, given studies documenting long-distance fluvial travel of zircons from their sources [e.g., Dickinson and Gehrels, 2009]. 


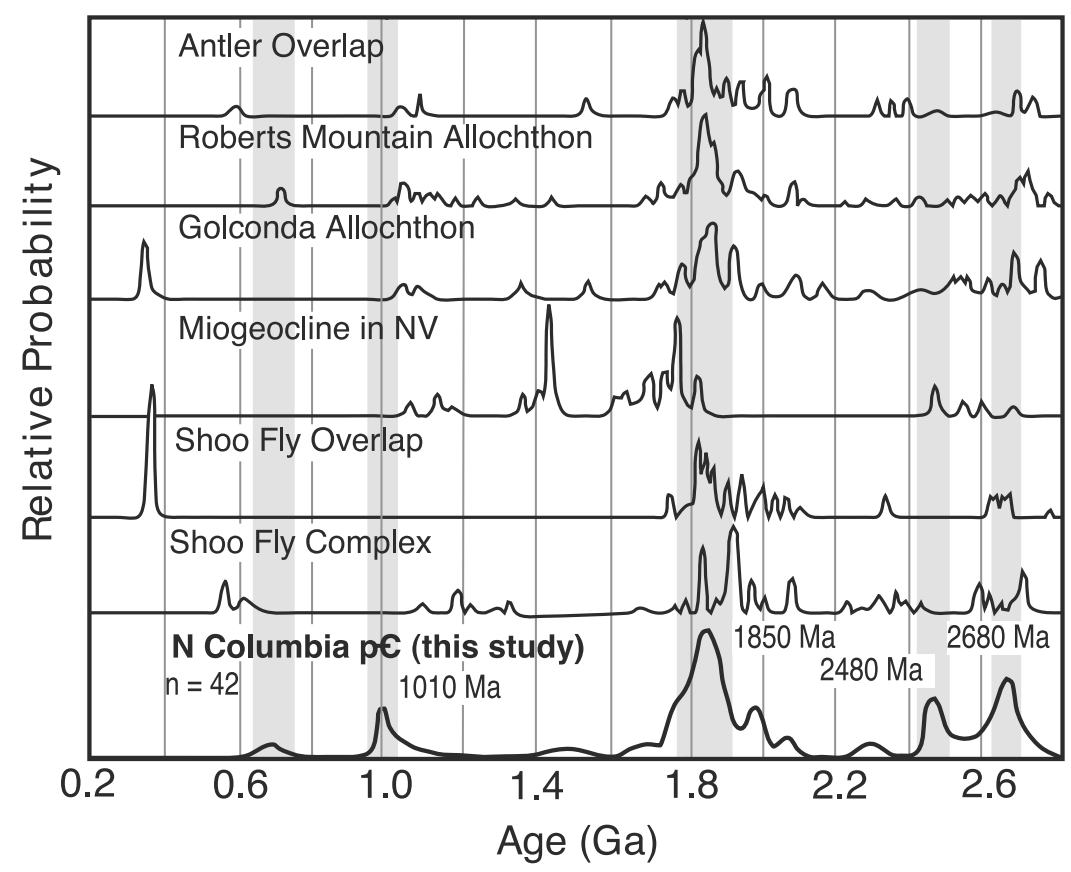

Figure 5. Comparison of pre-Mesozoic relative age-probability plots from basement terranes in the Sierra Nevada, Nevada, and from North Columbia Precambrian sample reported here (basement terranes are shown in Figure 1). Detrital zircon age distributions are from Antler Overlap [Gehrels and Dickinson, 2000], Roberts Mountain allochthon, [Gehrels et al., 2000], Golconda allochthon, [Riley et al., 2000], miogeocline in Nevada [Gehrels et al., 1995], Shoo Fly Complex [Harding et al., 2000], Shoo Fly overlap [Spurlin et al., 2000].

[25] Zircon population distributions dominated by Mesozoic batholithic ages could be the result of exclusively local sourcing, as we have suggested here. Alternatively, it is possible that paleorivers drained terranes other than the Mesozoic batholith, but that those terranes were either zirconpoor, or lithologically less likely to contribute zircons to the river's sediment load. Detrital zircon populations of Late Cretaceous through Eocene sedimentary deposits of the Sheep Pass basin (central Nevada), however, are dominated by Precambrian detrital zircon populations, suggesting that zircon grains were exposed and available for transport and deposition during that time [Druschke et al., 2009]. The data from the Sheep Pass basin further indicate that sedimentary strata, which primarily make up the Nevada basement terranes, are abundant sources of detrital zircon grains. It is unlikely, therefore, that the overwhelming Mesozoic batholithic signatures present in our sample data are the result of lithologic bias.

[26] A recent study by Van Buer et al. [2009] suggests that batholithic granitoid rocks exposed during the Eocene extended beyond the current geomorphic bounds of the Sierra Nevada and into northwestern Nevada. This would indicate that a paleodrainage divide to the east of the modern one would still be consistent with the detrital zircon data presented here. This is problematic for two reasons. First, given their paleogeologic reconstruction and the proposed location of the paleodrainage divide, Eocene river systems with headwaters in east central Nevada should contain detritus derived from not only batholithic rocks, but also
Paleozoic strata of the miogeocline and its lower Mesozoic overlap, and Paleozoic eugeoclinal strata of the Golconda and Roberts Mountain allochthons. This is particularly the case for paleofluvial samples collected from locations south of $39^{\circ} \mathrm{N}$, where the more easterly extent of the batholithic rocks is not observed. Second, reported ages of granitoid rocks in northwestern Nevada overlap with, but are slightly younger than, those in the main Sierra Nevada batholith (105-85 Ma [Smith et al., 1971]), and are underrepresented in our $\mathrm{U}-\mathrm{Pb}$ detrital zircon age spectra. The documented ages of Nevada plutons between $38^{\circ} \mathrm{N}$ and $41^{\circ} \mathrm{N}$, normalized to their estimated surface areas (data from the updated CONTACT88 database [Barton et al., 1988]), indicate that the main magmatic peak in Nevada between those latitudes postdates that of the main body of the Sierra Nevada (Figure 7). Furthermore, plutonic rocks comprise a much smaller fraction of the total surface area of Nevada $(\sim 6 \%)$, compared to that of the northern Sierra Nevada $(>25 \%)$. These estimates are based on modern exposures, however, and do not take into account post-Eocene extension, erosion, or deposition, and so should be considered minimum estimates.

\subsection{Implications for the Paleotopography of the Central Northern Sierra Nevada}

[27] The interpretation that detrital zircons in Eocene fluvial deposits are derived overwhelmingly from the main Sierra Nevada batholith and associated Paleozoic terranes has implications for the paleotopography of the area. First, it 


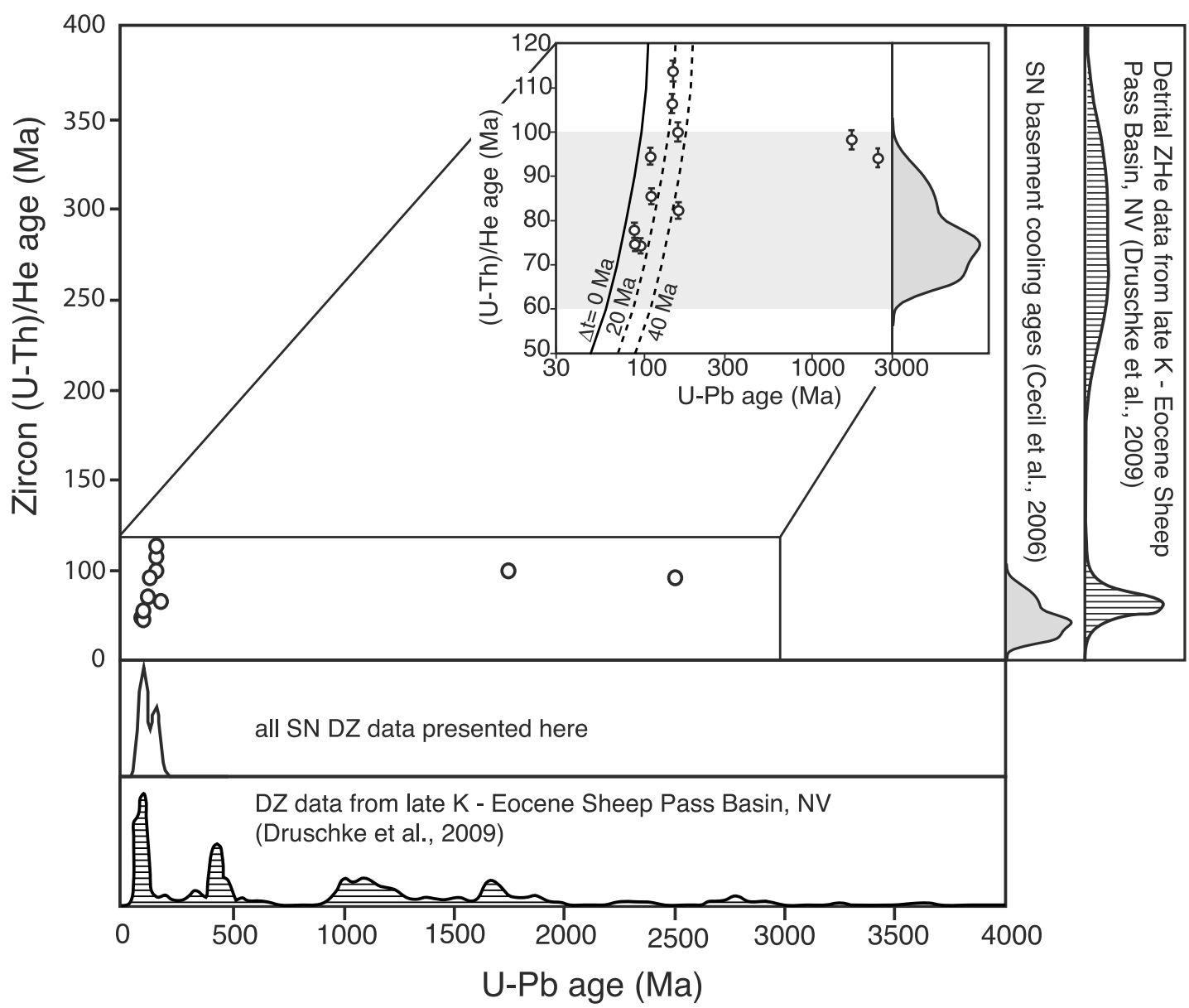

Figure 6. Detrital U-Pb and (U-Th)/He double dates of zircon grains from the Blue Lead sand sample (3a; Figure 2). (U-Th)/He ages are compared to (U-Th)/He zircon ages from Sierran bedrock samples (curve at right [from Cecil et al., 2006]) and to detrital (U-Th)/He cooling ages of zircons from the late Cretaceous-Eocene Sheep Pass Basin, east central Nevada [from Druschke et al., 2009]. U-Pb ages are compared to both the total distribution of detrital zircon ages measured here (Precambrian grains are of such low relative abundance that they do not plot visibly) and detrital zircon ages from the Sheep Pass Basin [Druschke et al., 2009]. For clarity, our double-dated grains are shown again at different scale in the inset. U-Pb ages in the inset are plotted on a logarithmic scale. At such a scale, error bars are not visible. Zircon (U-Th)/He ages lie below, and are parallel to, the 1:1 $\mathrm{He} / \mathrm{Pb}$ line (difference between crystallization and cooling age is zero; $\Delta \mathrm{t}=0 \mathrm{Ma}$ ), as is expected for plutonic samples. Most grains fall within $\Delta \mathrm{t}$ contours drawn at $20 \mathrm{Ma}$ and $40 \mathrm{Ma}$, indicating rapid cooling in the late Cretaceous, which is consistent with interpretations of bedrock cooling ages. Two multicycle grains (defined as those grains having $\Delta \mathrm{t}>300 \mathrm{Ma}$ [Campbell et al., 2005]) have similar cooling ages, suggesting a common exhumation history. This is in contrast to similar ages detritus in Nevada, which has both Cretaceous and Permian cooling ages.

implies areally limited catchments, suggesting that paleorivers had shorter axial lengths and steeper axial gradients than previously estimated. Second, it implies that the Eocene drainage divide was positioned within the Sierran block, which acted as a topographic barrier separating the paleoPacific Ocean from inboard Nevadan terranes. Although the detrital zircon geochronometry data presented here cannot constrain the paleoelevation of the source area, when combined with independent paleoaltimetry from the adjacent Great Basin, they can be used to estimate the gradient of the western Sierran slope, and minimum summit elevations.
[28] It has been suggested that the Paleogene Great Basin was part of a high $(\geq 3 \mathrm{~km})$ interior highland, the Nevadaplano, which formed as a result of orogenic thickening and compression in the Mesozoic [Dilek and Moores, 1999; DeCelles, 2004]. Geophysical and thermobarometric data [Wernicke et al., 1996] and geochemical data from Cenozoic volcanics [Best et al., 2009] have been used to argue for the presence of thickened $(50-70 \mathrm{~km})$ crust in Nevada at that time, which was likely isostatically compensated by elevated topography. High paleoelevations of an interior continental highland $(2-3 \mathrm{~km})$ are supported by stable isotope 


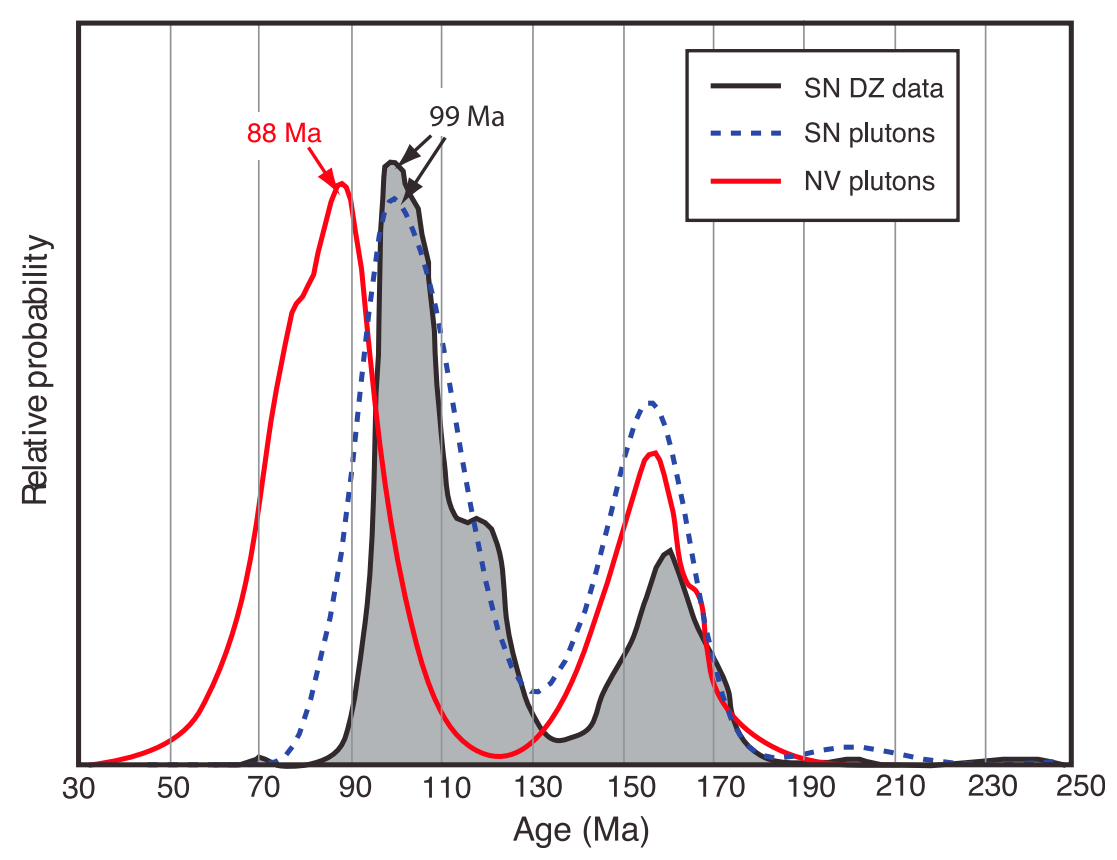

Figure 7. Relative probability curves for ages of Sierra Nevada plutons within area shown in Figure 2a and ages of Nevada plutons between $38^{\circ} \mathrm{N}$ and $41^{\circ} \mathrm{N}$, both normalized to surface area. Pluton probability curves are compared to the relative probability plot of all Sierran detrital zircon data reported in this paper. Main Cretaceous peaks in the Sierra Nevada and Nevada are offset by 11 Myr. It should be noted that at present, Mesozoic plutons make up only $6 \%$ of the total Nevada surface area within the latitude bounds chosen, whereas $>25 \%$ of the surface area of the northern Sierra Nevada today is composed of plutonic rocks. Exposed pluton area would presumably have been higher during the Eocene in both the Sierra Nevada and Nevada.

[Horton et al., 2004; Mulch et al., 2006; Cassel et al., 2009a], organic molecular [Hren et al., 2010], and paleobotanical altimetric proxies [Wolfe et al., 1998, 1997]. Although multiple lines of evidence point at high late Cretaceous-mid-Cenozoic elevations in Nevada, it should be noted that both stable isotope and botanically based paleoaltimetric estimates can be subject to very large (>1 km) uncertainties [Molnar, 2010; Peppe et al., 2010].

[29] Conservatively assigning a mean elevation of $\sim 1.5-$ $2 \mathrm{~km}$ to the highlands further east, and assuming that the Eocene Sierra Nevada crest acted as a regionally developed drainage divide, paleoelevations of the Sierran crest were likely at least that high. Given the proximity of the Eocene shoreline (Figure 1) to the paleocrest $(\sim 80-120 \mathrm{~km}$, depending upon latitudinal position and the inferred eastern extent of the Sierran batholith), and the minimum estimate of Eocene summit elevations, the gradient of the western slope can be estimated to be between 0.7 and $1.4^{\circ}$. This is similar to the modern gradient of $1.3^{\circ}$, at the latitude of the Yuba River $\left(\sim 39^{\circ} \mathrm{N}\right)$, and consistent with stable isotope based paleoaltimetry estimates, which suggest Eocene through Pleistocene long-lived topography similar to that of today [Mulch et al., 2006, 2008; Crowley et al., 2008; Cassel et al., 2009a].

[30] We hypothesize that the Sierra Nevada acted as a western boundary to a continental interior highland further east, separating it from the paleo-Pacific by a topographically higher drainage divide (Figure $8 \mathrm{a}$ ). The overall topo- graphic structure of the Sierra Nevada in the Eocene would have been very similar to that produced in the Late Cretaceous following emplacement and exhumation of the batholith [DeGraaff-Surpless et al., 2002], suggesting the preservation of large-scale relief and elevation into the Paleogene. Our interpretation is consistent with estimates of Eocene Sierran relief by Mulch et al. [2006], and agree with studies supporting the Sierra Nevada existing as a major topographic feature throughout the Cenozoic [e.g., House et al., 1998, 2001; Poage and Chamberlain, 2002; Braun, 2002; Pelletier, 2007; Mulch et al., 2008]. They are not consistent, however, with a model of low-gradient Eocene rivers $\left(0.1^{\circ}-0.2^{\circ}\right.$ [Jones et al., 2004]) draining a low-slope surface, potentially extending tens to hundreds of kilometers east of the modern divide, as has been suggested based on the proposed sinuosity and alluviated nature of the paleorivers (Figure 8b) [Lindgren, 1911; Christensen, 1966; Huber, 1981; Wakabayashi and Sawyer, 2001; Jones et al., 2004]. Our results, however, do not preclude a scenario in which the post-Eocene Sierra experienced tilting or moderate regional uplift due to more recent tectonic causes.

[31] It has been suggested that a Sierran divide was not present during the Oligocene, when ash flow tuffs, sourced in the central Nevada caldera belt, were being deposited in paleochannels draining across the modern divide and onto the western Sierran slope [Busby et al., 2008; Cassel et al., 2009b]. During this time, it is hypothesized that the Sierra Nevada acted as a continuous, west dipping shoulder to the 


\section{Models of Eocene topography}
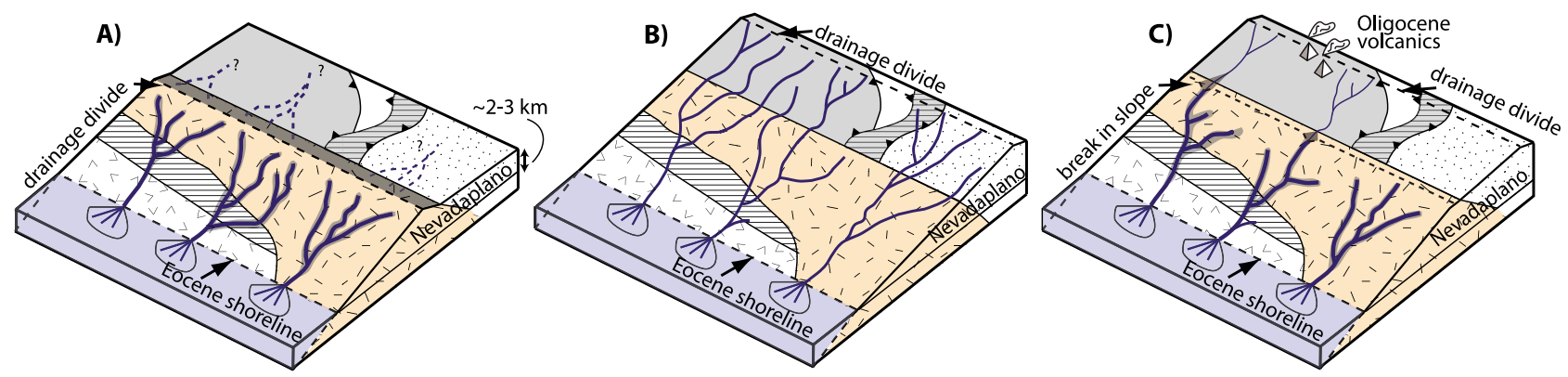

California

Sierra Nevada batholith

Foothills belt $(\mathrm{J})$

Northern Sierra terrane
Nevada

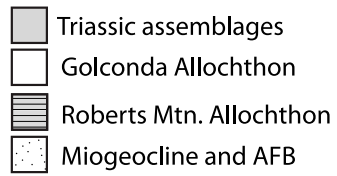

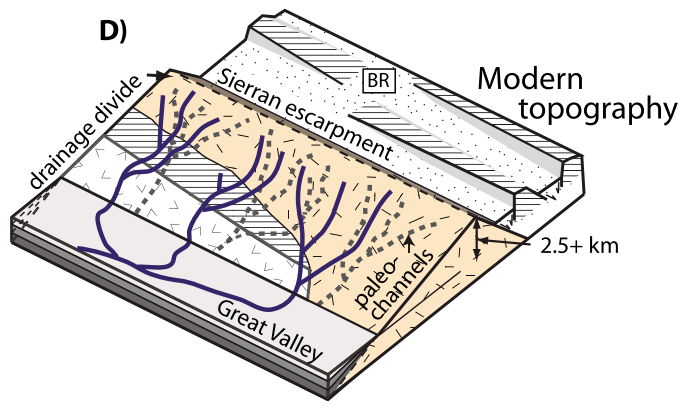

Figure 8. Schematic block models representing $(\mathrm{a}-\mathrm{c})$ Eocene and $(\mathrm{d})$ modern topographic configurations of the Sierra Nevada and adjacent Nevada highlands (Eocene)/Basin and Range (modern). Figure 8a shows paleotopography of the Sierra Nevada best supported by the detrital zircon data presented herein. A drainage divide, in roughly the same position as that of the modern one, separates the Sierra from the interior Nevadaplano. Paleorivers are relatively steep, with small catchments, sourced entirely within the Sierra Nevada block. Crestal elevations are assumed to be at least $1.5 \mathrm{~km}$, based on paleoelevation estimates for the Nevadaplano. The western flank of the Sierra slopes westward at a gradient similar to the modern one. Figure $8 \mathrm{~b}$ shows traditional model of Sierra Nevada paleotopography based on a regionally developed erosion surface and the meandering and alluviated nature of Eocene rivers. This model implies a shallow gradient for the western Sierran flank, with relatively low-slope rivers draining a large area, and is a poor fit to the detrital zircon data presented here. In Figure 8c paleorivers drain westward across the Nevadaplano in nonerosive channels but must incise and exclusively incorporate Sierran detritus to the west to be consistent with our provenance data. This model requires a change in slope or some other mechanism for changing erosive power of the paleorivers at or near the modern divide but has the benefit of not requiring a large $(>150 \mathrm{~km})$ eastward shift in drainage divide position before deposition of Oligocene ash flows in Sierran paleorivers. In Figure $8 \mathrm{~d}$ the period from $\sim 5 \mathrm{Ma}$ to the present is marked by the extensional collapse of the nearby Nevada highlands and the development of the Sierran frontal escarpment, perhaps accompanied by moderate uplift of the range crest. Paleochannels (gray dashed) are abandoned, and modern drainages (dark blue) are incised. BR, Basin and Range.

Nevadaplano. This would require (1) that the Sierra Nevada crest be lowered with respect to the Nevadaplano in the Eocene-Oligocene, such that large volumes of ignimbrites are allowed to flow across the divide and fill existing paleochannels, and (2) migration of the drainage divide eastward to central eastern Nevada. It is possible that parts of the ancestral Sierran crest were lowered with respect to the adjacent highlands and paleochannels became integrated across the crest. Channel integration is expected to generate knickpoints in the paleoriver systems where stream channels experience a break in slope crossing from the relatively low relief Nevadaplano to the western Sierra. Headward erosion resulting from knickpoint generation and migration could explain an earlier ( 20-3 Ma) documented phase of incision in Sierran rivers [Clark et al., 2005; Clark and Farley, 2007; Saleeby et al., 2009]. Alternatively, it is possible that the
Oligocene topographic configuration described above existed in the Eocene, such that paleorivers drained westward across the Nevadaplano, but their eastern reaches were not acting as erosive channels (Figure 8c). Only after experiencing an increase in erosive stream power, drawn as an increase in slope in the block model, would the paleorivers start to incorporate detritus with Sierra Nevada affinity. This model honors the detrital zircon data presented here, without requiring a shift in drainage divide position or a relative change in elevation between the Sierra and the Nevadaplano.

[32] It is not until Miocene-Pliocene encroachment of Basin and Range faulting and the development of the Sierran frontal escarpment that the Sierran drainage divide is fully reestablished (Figure 8d). Detailed chronostratigraphy of volcanics and volcaniclastics from central Sierran paleochannels indicates that they were cut off from sources to the 
east between 10 and $7 \mathrm{Ma}$ [Busby et al., 2008; Busby and Putirka, 2009]. Renewed late Cenozoic river incision and a reorganization of modern rivers systems away from paleochannels now clogged with Miocene lahars also occurs during this time. It is unclear, however, whether this change in river behavior is associated with tectonic forcing, a shift in climate, or both. Regardless of the mechanism, some perturbation is necessary to account for the reorganization of drainage networks and to explain why Eocene rivers, which were apparently draining an area similar to the modern ones, were predominantly alluvial, less incised, and more sinuous than their modern counterparts.

\section{Conclusions}

[33] The geochronologic and thermochronologic signatures of detrital zircons from Eocene river sediments preserved along the western flank of the northern Sierra Nevada allow us to constrain the source areas of the rivers transporting that sediment and to infer large-scale characteristics of Sierran paleotopography. Detrital zircon U-Pb age spectra are dominated by Mesozoic peaks, the proportion and distribution of which are an excellent match to the timing of known volumetric fluxes in Sierran magmatic production, and distinct from Mesozoic pluton ages in Nevada. Patterns observed in the Jurassic grain populations also tie detrital zircons to local batholithic sources. Precambrian grains, although few, are also interpreted to be of Sierran affinity based on the distribution of their $\mathrm{U}-\mathrm{Pb}$ and $(\mathrm{U}-\mathrm{Th}) / \mathrm{He}$ ages, which are different than those reported for similarly aged fluvial sediments in Nevada [Druschke et al., 2009]. Zircon He ages of double- dated grains are similar to bedrock cooling ages of northern Sierra granitoids and indicate derivation from a single source with a Sierra-like unroofing history. These data suggest that Eocene rivers were draining smaller, local catchments and had headwaters within the confines of the Sierra Nevada block, implying that the Eocene drainage divide was in a position similar to the modern one.

[34] Although the Sierra Nevada preserves a Paleogene erosion surface, commonly interpreted to be indicative of local relief reduction, our data suggest that the Eocene Sierra was characterized by modest to high crestal elevations and a western flank with a gradient similar to the modern one. This in turn suggests that (1) the depositional gradient of Eocene rivers was likely similar to the gradient at which they are preserved today, which argues against significant post-Eocene crestal uplift of the range block in the northern Sierra Nevada, and (2) low-relief surfaces, such as the relict Sierran landscape [Clark et al., 2005] do not necessarily develop at low elevations.

[35] Acknowledgments. We thank Jim Wood for his assistance in the field and Victor Valencia for his help with $\mathrm{U}-\mathrm{Pb}$ zircon analysis. This work was supported by NSF-EAR 0606967 to M. Ducea, Arizona LaserChron Center NSF-EAR 0732426 to G. Gehrels, and graduate students research scholarships from Chevron and the Geological Society of America to M. R. Cecil. A.M. acknowledges support through the LOEWE funding program of Hesse's Ministry of Higher Education, Research, and the Arts. The authors thank J. Saleeby for a critical discussion of the paper and Greg Stock and an anonymous reviewer for thoughtful and thorough reviews, all of which significantly improved the manuscript.

\section{References}

Argus, D. F., and R. G. Gordon (1991), Current Sierra Nevada-North America motion from very long baseline interferometry: Implications for the kinematics of the western United States, Geology, 19(11), 1085-1088, doi:10.1130/0091-7613(1991)019< 1085: CSNNAM $>2.3 . \mathrm{CO} ; 2$.

Barton, M. D., et al. (1988), Mesozoic contact metamorphism in the western United States, in Metamorphism and Crustal Evolution of the Western United States, edited by W. G. Ernst, pp. 110-178, PrenticeHall, Englewood Cliffs, N. J.

Bateman, P. C., and C. Wahrhaftig (1966), Geology of the Sierra Nevada, in Geology of Northern California, edited by E. H. Bailey, pp. 107-172, Calif. Div. of Mines and Geol., San Francisco, Calif.

Best, M. G., et al. (2009), The Great Basin Altiplano during the middle Cenozoic ignimbrite flareup: Insights from volcanic rocks, Int. Geol. Rev., 51(7-8), 589-633, doi:10.1080/00206810902867690.

Braun, J. (2002), Quantifying the effect of recent relief changes on age-elevation relationships, Earth Planet. Sci. Lett., 200(3-4), 331-343, doi:10.1016/S0012821X(02)00638-6.

Busby, C. J., and K. Putirka (2009), Miocene evolution of the western edge of the Nevadaplano in the central and northern Sierra Nevada: Palaeocanyons, magmatism, and structure, Int. Geol. Rev., 51(7-8), 670-701, doi:10.1080/00206810902978265.

Busby, C. J., et al. (2008), Carson Pass-Kirkwood paleocanyon system: Paleogeography of the ancestral Cascades arc and implications for landscape evolution of the Sierra Nevada (California), Geol. Soc. Am. Bull., 120(3), 274-299, doi:10.1130/ B25849.1.

Campbell, I. H., et al. (2005), He-Pb double dating of detrital zircons from the Ganges and Indus rivers:
Implication for quantifying sediment recycling and provenance studies, Earth Planet. Sci. Lett., 237(3-4), 402-432, doi:10.1016/j.epsl.2005.06.043.

Cassel, E. J., et al. (2009a), Cenozoic tectonic and topographic evolution of the northern Sierra Nevada, California, through stable isotope paleoaltimetry in volcanic glass, Geology, 37(6), 547-550, doi:10.1130/G25572A.1.

Cassel, E. J., et al. (2009b), Age, geochemical composition, and distribution of Oligocene ignimbrites in the northern Sierra Nevada, California: Implications for landscape morphology, elevation, and drainage divide geography of the Nevadaplano, Int. Geol. Rev. 51(7-8), 723-742, doi:10.1080/00206810902880370.

Cecil, M. R., et al. (2006), Cenozoic exhumation of the northern Sierra Nevada, California, from $(\mathrm{U}-\mathrm{Th}) / \mathrm{He}$ thermochronology, Geol. Soc. Am. Bull., 118(11), 1481-1488, doi:10.1130/B25876.1.

Christensen, M. N. (1966), Late Cenozoic crustal movements in the Sierra Nevada of California, Geol. Soc. Am. Bull., 77(2), 163-182, doi:10.1130/0016-7606 (1966)77[163:LCCMIT]2.0.CO;2.

Clark, M. K., and K. A. Farley (2007), Sierra Nevada river incision from apatite ${ }^{4} \mathrm{He} /{ }^{3} \mathrm{He}$ thermochronometry, Eos Trans. $A G U, 88(52)$, Fall Meet. Suppl., Abstract T31E-03.

Clark, M. K., et al. (2005), The non-equilibrium landscape of the southern Sierra Nevada, California, GSA Today, 15, 4-10, doi:10.1130/1052-5173 (2005)015[4:TNLOTS]2.0.CO;2.

Clark, W. B. (1979), Stream channel deposits of the Tertiary period: Fossil river beds of the Sierra Nevada, Calif. Geol., 32, 143-149.

Coleman, D. S., and A. F. Glazner (1998), The Sierra crest magmatic event: Rapid formation of juvenile crust during the late Cretaceous in California, in
Integrated Earth and Environmental Evolution of the Southwestern United States, edited by W. G. Ernst and C. A. Nelson, pp. 253-272, Bellwether, Columbia, Md.

Crafford, A. E. J. (2007), Geologic Map of Nevada [CD-ROM], Data Ser., vol. 249, 46 pp., U.S. Geol. Surv., Denver, Colo. (Available at http://pubs.usgs. gov/ds/2007/249/.)

Creely, S., and E. R. Force (2007), Type region of the Ione Formation (Eocene), Central California: Stratigraphy, paleogeography, and relation to auriferous gravels, U.S. Geol. Surv. Open File Rep., 2006$1378,65 \mathrm{pp}$.

Crowley, B. E., et al. (2008), Stable isotope constraints on the elevation history of the Sierra Nevada Mountains, California, Geol. Soc. Am. Bull., 120(5), 588-598, doi:10.1130/B26254.1.

DeCelles, P. G. (2004), Late Jurassic to Eocene evolution of the Cordilleran thrust belt and foreland basin system, western USA, Am. J. Sci., 304(2), 105-168, doi: 10.2475/ajs.304.2.105.

DeGraaff-Surpless, K., et al. (2002), Detrital zircon provenance analysis of the Great Valley Group, California: Evolution of an arc-forearc system, Geol. Soc. Am. Bull., 114(12), 1564-1580, doi:10.1130/ 0016-7606(2002)114<1564:DZPAOT >2.0.CO;2.

Dickinson, W. R., and G. E. Gehrels (2009), U-Pb ages of detrital zircons in Jurassic eolian and associated sandstones of the Colorado Plateau: Evidence for transcontinental dispersal and intraregional recycling of sediment, Geol. Soc. Am. Bull., 121(3-4), 408-433, doi:10.1130/B26406.1.

Dilek, Y., and E. Moores (1999), A Tibetan model for the early Tertiary western United States, J. Geol. Soc., 156(5), 929-941, doi:10.1144/gsjgs.156.5.0929. 
Dixon, T. H., M. Miller, F. Farina, H. Wang, and D. Johnson (2000), Present-day motion of the Sierra Nevada block and some tectonic implications for the Basin and Range province, North American Cordillera, Tectonics, 19(1), 1-24, doi:10.1029/ 1998TC001088.

Dodge, F. C. W., and L. C. Calk (1987), Geologic map of the Lake Eleanor Quadrangle, central Sierra Nevada, California, in Geologic Quadrangle Map, 1 sheet, Rep. GQ-1639, U.S. Geol. Surv., Denver, Colo.

Druschke, P., et al. (2009), Synconvergent surfacebreaking normal faults of Late Cretaceous age within the Sevier hinterland, east-central Nevada, Geology, 37(5), 447-450, doi:10.1130/G25546A.1.

Ducea, M. (2001), The California arc: Thick granitic batholiths, eclogitic residues, lithospheric-scale thrusting and magmatic flare-ups, GSA Today, 11 , 4-10, doi:10.1130/1052-5173(2001)011<0004: TCATGB $>2.0 . \mathrm{CO} ; 2$

Faulds, J. E, et al (2005), Kinematics of the northern Walker Lane: An incipient transform fault along the Pacific-North American plate boundary, Geology, 33(6), 505-508, doi:10.1130/G21274.1.

Garside, L. J., et al. (2005), The upper reaches of the Sierra Nevada auriferous gold channels, California and Nevada, in Geological Society of Nevada Symposium 2005: Window to the World, edited by H. N. Rhoden et al., pp. 209-235, Geol. Soc. of Nev., Reno.

Gehrels, G. E., and W. R. Dickinson (2000), Detrital zircon geochronology of the Antler overlap and foreland basin assemblages, in Paleozoic and Triassic Paleogeography and Tectonics of Western Nevada and Northern California, edited by M. J. Soreghan and G. Gehrels, Spec. Pap. Geol. Soc. Am., 347, 57-63, doi:10.1130/0-8137-2347-7.57.

Gehrels, G. E., and M. M. Miller (2000), Detrital zircon geochronologic study of upper Paleozoic strata in the eastern Klamath terrane, northern California, in Paleozoic and Triassic Paleogeography and Tectonics of Western Nevada and Northern California, edited by M. J. Soreghan and G. Gehrels, Spec. Pap. Geol. Soc. Am., 347, 99-107, doi:10.1130/08137-2347-7.99.

Gehrels, G. E., et al. (1995), Detrital zircon reference for Cambrian to Triassic miogeoclinal strata of western North America, Geology, 23(9), 831-834, doi: 10.1130/0091-7613(1995)023<0831: DZRFCT $>2.3$.CO;2.

Gehrels, G. E., et al (2000), Detrital zircon geochronology of the Roberts Mountains allochthon, Nevada, in Paleozoic and Triassic Paleogeography and Tectonics of Western Nevada and Northern California, edited by M. J. Soreghan and G. Gehrels, Spec. Pap. Geol. Soc. Am., 347, 19-42, doi:10.1130/ 0-8137-2347-7.19.

Gehrels, G. E., V. A. Valencia, and J. Ruiz (2008), Enhanced precision, accuracy, efficiency, and spatial resolution of $\mathrm{U}-\mathrm{Pb}$ ages by laser ablationmulticollector-inductively coupled plasma-mass spectrometry, Geochem. Geophys. Geosyst., 9, Q03017, doi:10.1029/2007GC001805.

Harding, J. P., et al. (2000), Detrital zircon geochronology of the Shoo Fly Complex, northern Sierra terrane, northeastern California, in Paleozoic and Triassic Paleogeography and Tectonics of Western Nevada and Northern California, edited by M. J. Soreghan and G. Gehrels, Spec. Pap. Geol. Soc. Am., 347, 43-55.

Henry, C. D. (2008), Ash-flow tuffs and paleovalleys in northeastern Nevada: Implications for Eocene paleogeography and extension in the Sevier hinterland, northern Great Basin, Geosphere, 4(1), 1-35, doi:10.1130/GES00122.1.

Horton, T. W., et al. (2004), Spatial and temporal variation of Cenozoic surface elevation in the Great Basin and Sierra Nevada, Am. J. Sci., 304(10), 862-888, doi:10.2475/ajs.304.10.862

House, M. A., et al. (1998), Dating topography of the Sierra Nevada, California, using apatite (U-Th)/He ages, Nature, 396(6706), 66-69, doi:10.1038/ 23926.

House, M. A., et al. (2001), Paleo-geomorphology of the Sierra Nevada, California, from (U-Th)/He ages in apatite, Am. J. Sci., 301(2), 77-102, doi:10.2475/ ajs.301.2.77.

Hren, M. T., et al. (2010), Biomarker reconstruction of the early Eocene paleotopography and paleoclimate of the northern Sierra Nevada, Geology, 38(1), 7-10, doi:10.1130/G30215.1.

Huber, N. K. (1981), Amount and timing of Late Cenozoic uplift and tilt of the central Sierra Nevada, California-Evidence from the upper San Joaquin River basin, U.S. Geol. Surv. Prof. Pap., 1197, 28 pp.

Huber, N. K. (1990), The Late Cenozoic evolution of the Tuolumne River, central Sierra Nevada, California, Geol. Soc. Am. Bull., 102(1), 102-115, doi:10.1130/ 0016-7606(1990)102<0102:TLCEOT>2.3.CO;2.

Hudson, F. S. (1955), Measurement of the deformation of the Sierra Nevada, California, since Middle Eocene, Geol. Soc. Am. Bull., 66(7), 835-869, doi:10.1130/0016-7606(1955)66[835:MOTDOT] 2.0.CO;2.

Hudson, F. S. (1960), Post Pliocene uplift of the Sierra Nevada, California, Geol. Soc. Am. Bull., 71(11), $1547-1574$.

Irwin, W. P., and J. L. Wooden (2001), Plutons and accreted terranes of the Sierra Nevada, California, U.S. Geol. Surv. Open File Rep., 99-0374.

Jones, C. H., et al. (2004), Tectonics of Pliocene removal of lithosphere of the Sierra Nevada, California, Geol. Soc. Am. Bull., 116(11), 1408-1422, doi:10.1130/ B25397.1.

Lindgren, W. (1911), The Tertiary gravels of the Sierra Nevada, U.S. Geol. Surv. Prof. Pap., 73, 226 pp.

Mahéo, G., J. Saleeby, Z. Saleeby, and K. A. Farley (2009), Tectonic control on southern Sierra Nevada topography, California, Tectonics, 28, TC6006, doi:10.1029/2008TC002340.

Molnar, P. (2010), Deuterium and oxygen isotopes, paleoelevations of the Sierra Nevada, and Cenozoic climate, Geol. Soc. Am. Bull., 122(7-8), 1106-1115, doi:10.1130/B30001.1.

Mulch, A., et al. (2006), Hydrogen isotopes in Eocene river gravels and paleoelevation of the Sierra Nevada, Science, 313(5783), 87-89, doi:10.1126/ science. 1125986

Mulch, A., et al. (2008), A Miocene to Pleistocene climate and elevation record of the Sierra Nevada (California), Proc. Natl. Acad. Sci. U. S. A., 105(19), 6819-6824, doi:10.1073/pnas.0708811105.

Pelletier, J. (2007), Numerical modeling of the Cenozoic geomorphic evolution of the southern Sierra Nevada, California, Earth Planet. Sci. Lett., 259(1-2), 85-96, doi:10.1016/j.eps1.2007.04.030.

Peppe, D. J., D. L. Royer, P. Wilf, and E. A. Kowalski (2010), Quantification of large uncertainties in fossil lead paleoaltimetry, Tectonics, 29, TC3015, doi:10.1029/2009TC002549.

Poage, M. A., and C. P. Chamberlain (2002), Stable isotopic evidence for a Pre-Middle Miocene rain shadow in the western Basin and Range: Implications for the paleotopography of the Sierra Nevada, Tectonics, 21(4), 1034, doi:10.1029/2001TC001303.

Reiners, P. W., et al. (2005), (U-Th)/(He-Pb) double dating of detrital zircons, Am. J. Sci., 305(4), 259-311, doi:10.2475/ajs.305.4.259.

Riley, B. C. D., et al. (2000), U-Pb detrital zircon geochronology of the Golconda allochthon, Nevada, in Paleozoic and Triassic Paleogeography and Tectonics of Western Nevada and Northern California, edited by M. J. Soreghan and G. Gehrels, Spec. Pap. Geol. Soc. Am., 347, 65-75.

Saleeby, J., et al. (2009), Step-over in the structure controlling the regional west tilt of the Sierra Nevada microplate: Eastern escarpment system to Kern Canyon system, Int. Geol. Rev., 51(7-8), 634-669, doi:10.1080/00206810902867773.

Schweickert, R. A., and W. S. Snyder (1981), Paleozoic plate tectonics of the Sierra Nevada and adjacent regions, in The Geotectonic Development of Califor- nia, edited by W. G. Ernst, pp. 183-201, PrenticeHall, Englewood Cliffs, N. J.

Sharp, W. D., and J. B. Saleeby (1979), The Calaveras Formation and syntectonic mid-Jurassic pluton between the Stanislaus and Tuolumne rivers, California Geol. Soc. Am. Abstr. Programs, 11, 127.

Smith, J. G., et al. (1971), Mesozoic granitic rocks in northwestern Nevada: A link between the Sierra Nevada and Idaho batholiths, Geol. Soc. Am. Bull., 82(10), 2933-2944, doi:10.1130/0016-7606(1971) 82[2933:MGRINN]2.0.CO;2

Smith, J. G., et al. (1991), Palinspastic restoration of Cenozoic extension in the central and eastern Basin and Range Province at latitudes $39-40^{\circ} \mathrm{N}$, in Geology and Ore Deposits of the Great Basin: A Symposium, edited by G. L. Raines et al., pp. 75-86, Geol. Soc. of Nev., Reno.

Spurlin, M. S., et al. (2000), Detrital zircon geochronology of upper Paleozoic and lower Mesozoic strata of the northern Sierra terrane, northeastern California, in Paleozoic and Triassic Paleogeography and Tectonics of Western Nevada and Northern California, edited by M. J. Soreghan and G. Gehrels, Spec Pap. Geol. Soc. Am., 347, 89-98, doi:10.1130/08137-2347-7.89.

Stock, G. M., et al. (2004), Pace of landscape evolution in the Sierra Nevada, California, revealed by cosmogenic dating of cave sediments, Geology, 32(3), 193-196, doi:10.1130/G20197.1.

Stock, G. M., et al. (2005), Rates of erosion and topographic evolution of the Sierra Nevada, California inferred from cosmogenic ${ }^{26} \mathrm{Al}$ and ${ }^{10} \mathrm{Be}$ concentrations, Earth Surf. Processes Landforms, 30(8), 985-1006, doi:10.1002/esp.1258.

Surpless, B. E., D. F. Stockli, T. A. Dumitru, and E. L. Miller (2002), Two-phase westward encroachment of Basin and Range extension into the northern Sierra Nevada, Tectonics, 21(1), 1002, doi:10.1029/ $2000 \mathrm{TC} 001257$.

Unruh, J. R. (1991), The uplift of the Sierra Nevada and implications for late Cenozoic epeirogeny in the western Cordillera, Geol. Soc. Am. Bull., 103(11), 13951404, doi:10.1130/0016-7606(1991)103<1395: TUOTSN $>2.3 . \mathrm{CO} ; 2$

Van Buer, N. J., et al. (2009), Early Tertiary paleogeologic map of the northern Sierra Nevada batholith and the northwestern Basin and Range, Geology, 37(4), 371-374, doi:10.1130/G25448A.1.

Wakabayashi, J., and T. L. Sawyer (2001), Stream incision, tectonics, uplift, and evolution of topography of the Sierra Nevada, California, J. Geol., 109(5), 539-562, doi:10.1086/321962.

Wernicke, B., et al. (1996), Origin of high mountain in the continents: The southern Sierra Nevada, Science, 271(5246), 190-193.

Wolfe, J. A., et al. (1997), Paleobotanical evidence for high altitudes in Nevada during the Miocene, Science, 276(5319), 1672-1675, doi:10.1126/science.276. 5319.1672 .

Wolfe, J. A., et al. (1998), Paleobotanical evidence of Eocene and Oligocene paleoaltitudes in midlatitude western North America, Geol. Soc. Am. Bull., 110(5), 664-678, doi:10.1130/0016-7606(1998)110<0664 PEOEAO $>2.3 . \mathrm{CO} ; 2$.

Yeend, W. E. (1974), Gold-bearing gravel of the ancestral Yuba River, Sierra Nevada, California, U.S. Geol. Surv. Prof. Pap., 772, 39 pp.

C. Allen and I. Campbell, Research School of Earth Sciences, Australian National University, Bldg. 61, Mills Road, Canberra, ACT 0200, Australia.

M. R. Cecil, Division of Geological and Planetary Sciences, California Institute of Technology, MC 100-23, Pasadena, CA 91125, USA. (cecil@caltech.edu)

M. N. Ducea, G. Gehrels, and P. Reiners, Department of Geosciences, University of Arizona, 1040 E Fourth St., Bldg. 77, Tucson, AZ 85721, USA. A. Mulch, Biodiversity and Climate Research Centre, Senckenberganlage 25, D-60325 Frankfurt, Germany. 